Linguistik Terapan 14 (1) (2017): 10-18

Jurnal Linguistik Terapan Pascasarjana

Available online

http://jurnal.unimed.ac.id/2017/index.php/JLT-Unimed

\title{
THE CONVERSATIONAL STYLES BY MALE AND FEMALE SELLERS IN BUSINESS TRANSACTIONS AT TRADITIONAL MARKET "PASAR SENTOSA BARU" MEDAN
}

\author{
DIANA HAYATI PULUNGAN
}

Sumarsih

Didik Santoso

Linguistik Terapan bahasa Inggris Universitas Negeri Medan

Diterima Februari 2017; Disetujui April 2017; Dipublikasikan Juni 2017

\begin{abstract}
This research deals with the conversational styles by male and female sellers in business transactions at traditional market "Pasar Sentosa Baru" Medan. It was conducted using qualitative research design. The subjects of 8 persons namely 4 male sellers and 4 female sellers were taken which they produced 20 conversations for each genders. The ages ranged from 30 to 60 years old. They come from various sellers, namely fish, chicken, vegetables, fruits, and spice. The instruments of collecting data were observation, recording, field notes, and interviewing adopted by Miles, Huberman, and Saldana (2014). The findings show that there were five types of conversational styles used by male and female sellers. In conversational styles used by male sellers; amount of talk (30\%), interruption $(26.7 \%)$, conversational support $(21.7 \%)$, compliment $(16.6 \%)$, and tentativeness (5\%). In conversational styles used by female sellers; interruption (29\%), amount of talk (23\%), conversational support (24\%), tentativeness (15\%), and compliment (9\%). In conversational styles in male sellers business transaction, the more dominant responses refer to talk of amount because they talk much in interaction in public context, while for female, the more dominant responses refer to interruption because the female sellers are taken as a violation and a sign of conversational dominance.
\end{abstract}

Keywords: Conversational styles, Gender, Traditional Market.

How to Cite: Pulungan, Diana Hayati (2017). 
The Conversational Styles by Male and Female Sellers in Business Transactions at Traditional Market "Pasar Sentosa Baru” Medan. Jurnal Linguistik Terapan Pascasarjana Unimed, 14 (1): 10-18

ISSN 2407-7410

\section{INTRODUCTION}

Women and men's talk in same-sex groups is an important and still developing area of language and gender. It has often been assumed in past research that women and men each form one homogeneous group, sharing one common social agenda and that their speech behavior can be explained by means of two simple generalizations: men's competitive speech style and women's cooperative speech style. Their different speech styles are achieved by characteristically drawing on different conversational strategies such as minimal responses, hedges, turn-taking patterns, interruptions and so on in conversational interactions.

According to Bergvall et al., Thakerar's (1982) speech accommodation theory describes "how speakers may vary their discourse behavior in accordance with their desire to signal allegiance to or divergence from other members of the group". (Bergvall et al., 1996:80) Through a large sample of conversations collection and then a systematic study of specific linguistic features, Bergvall et al. also reveals that women and men in their study display remarkably similar language behavior (Bergvall et al., 1996:60).

Women's speech is often described as tentative and women's speech style is always described as cooperative. This assertion is linked to the claim that women use more hedges. "Hedges are linguistic forms such as I think, I'm sure, you know, I mean, sort of and perhaps which express speaker's certainty and uncertainty about the proposition under discussion." (Coates, 2004:88) Hedges are used to mitigate the force of speakers' utterances and to save other speakers' face needs. According to Coates, Robin Lakoff (1975) explicitly links women's use of hedges with unassertness and argues that this is because women believe that asserting themselves strongly is not nice and less ladylike (Coates, 2004:88) . This is a claim based on no empirical evidence. Although some later relative studies made by linguists have proved that women use more hedges than men, contradictory findings have also shown that women and men similarly use some conversational strategies. as the research done by Bergvall et al. shows that, the occurrence of you know and the use of questions in men's conversation is nearly the same as those in women's conversations (Bergvall et al., 1996:60).

The importance of conversational style in a successful transaction is you sound spontaneous and natural despite through practice. Conversational style sounds as if you are talking to listeners rather than at them, sharing ideas with them rather than presenting a speech in front of them. One of the best ways to achieve this is to focus on sincerely trying to get your ideas across. It's also a great way to reduce speech anxiety, as getting a message accross is usually less stressful than performing. 
For generations, Indonesians have bought their food at traditional markets, pasar. The term pasar can refer to a gathering of tukang sayur (vendors who sell off carts which go through residential areas), to a rough, temporary structure where sellers gather in the morning, to the large, multistory buildings run by PD Pasar as market authority. The items sold in pasar are basically the same - fruit, vegetables, meat and fish, spices, dry goods and household items. Selection may vary slightly to better serve the needs of the ethnic groups which live in the area. In pasar, prices are not marked on items at traditional markets. Therefore, the fine art of bargaining is taken to new levels as housewives and household help try to get the cheapest prices possible.

Lakoff (1975) states that woman's language functions to express lack of confidence, uncertainty or tentativeness (Holmes, 1998). Lakoff (1975) argued that the use of hedging devices by women signal an evidence of their uncertainty, and boosting devices express their anticipations that the addressee may still unconvinced, so they need to supply another evidence (Holmes, 1998). Lakoff's (1975) methods of collecting and analyzing data were artificial as she collected her data in a laboratory with a screen between the speakers. The results also were contradictory, because many sociolinguists noted that men used more tag questions than women did, and some others found that there were no gender differences (Holmes, 1998).

There are so many pasar in Medan, that condition always happens which are men used more tag questions than women did, and some others found that there were no gender differences. The buyer of women's language consisting of certain linguistic features that connote tentativeness, deference and lack of authority. The reason, according to Cameron (1998) is that women are socialized into using this style of speech as part of their subordinate social position. On the other hand, the buyer of men's dominance in conversation parallel their dominance, power and authority in society. Men's linguistic patterns are regarded as ways in which they display power which is based in the larger social order but reinforced and expressed in face to face interaction with women (Henley \& Kramarae,1991).

Buyers and sellers in business transactions, each of which has a good hope. Expectations of the sellers are able to sell the merchandise easily and get great benefits, and expectations of buyers is able to buy goods at a very cheap price. In reality, expectations of buyers is very contrary to the expectations of the sellers. So often a small commotion during the business transactions. In every transaction, bargaining must always be done. There are many ways in which the two sides to avoid commotion during the transaction takes place, if in the process of bargaining is not going well, it is done by the seller is as follows:1. keep silent, 2. anger, 3. persuade, 4. describe the condition of goods. It is done for buyer is as follows: 1. leave the seller, 2. grumble, 3. persuade. Based on this situation, male talked too much in public context, he tendencies it is public context it is conducted that he feels. And it is needed to establish or maintain his status in that group.

In pasar, in order to merchandise quickly exhausted, sellers call consumers to buy their wares with chanted the price of their wares. And if buyers feel the price is cheap, then they will go to 
the seller. And if the buyers feel the price is quite expensive, so they will ignore the seller. But sometimes the buyers go directly to the seller although the seller does not call them. In every transaction, bargaining must always be done. One of the consequences of this concentration is a growing imbalance of bargaining power within transaction. In pasar, sellers characteristically say that they merely respond to consumers' wants and that, if they get it wrong, consumers will go elsewhere. However, it can be argued that they also play a key role in shaping consumer demand and that, because of the power they wield in the marketplace, they have a strong influence over what consumers buy, and how and where they buy it. Pasar can be seen as gatekeepers rather than passive transmitters of consumers' wishes, and their gate-keeping role can work to the detriment of consumers and suppliers alike.

Based on different sociolinguistics studies, which carried on investigating the differences between men's and women's language, most sociolinguists have agreed that women used more standard forms than men who tend to use vernaculars. According to Holmes (2008), there are different reasons for why women use more standard forms. First, the social norms of a society that we expect women's behavior as a model (guardian of society's values), this will affect the language they use. In addition, women are more status- cautious rather than men. Women are alleged by a stereotypical expectation when they speak, whatever they say "can be used against them as an evidence of their deficiencies" (Holmes,1985). Women also lack status in the society, so they "try to acquire it by using standard speech forms, and by reporting that they use even more of these forms than they actually do" (Holmes, 2008). By using standard forms, women fulfill their own face-protection needs and those they talk to. On the other hand, men use vernacular forms because they relate it to "masculinity and toughness" (Ibid:p.167). Other reasons why women use standard forms are that women were interviewed by male strangers and their sensitivity to contextual factors such as the topic raised during the conversation.

Nevertheless, researcher conducts gender, whereas gender is describing male and female do, it is determined how do male and female express their language use in due to interaction. Theoretically, male and female have different way in communication (Tannen: 1992), she says that male tends to use his logic to tell something, whereas female tends to use her emotion and feeling in conversation. Tannen (1992) adds six differences of communication between men and women, such as; status versus support, independence versus intimacy, advice versus understanding, information versus feeling, order versus proposal and conflict versus compromise. According to Swann (2000) based on empirical studies of gender and talk have documented a specific features of conversational styles, namely; amount of talk, tentativeness, conversational support, interruption, and compliments. These features are shown the different styles of male and female speakers in conversation.

In relation to the study, there are some previous researcher like Basirah (2012) in her study about "Gender Pattern on Facebook: A Sociolinguistic Perspective". This paper is summarized of tracing differences and similarities among the sexes use internet particularly social networking site, 
Facebook. And Nurul (2016) in her study about "Gender Language Characteristics of Twitter Participants of Different Culture". The differences exist on multiple levels and research shows that even on internet one is not a human being rather "man" or a "woman". All these have been exhibited through language and the choices they make. Researcher wants to see if the background of the culture of an area also refer able to influence the conversation and communication between the seller and the buyer in transaction of buying and selling are closely connected with the bargaining is done at the traditional market, beside to how seller can attract buyers to buy what they are selling. Being talked to, preached at, or lectured to by those trying to win business is generally felt as annoying, not persuasive. As clients don't respond to conventional, one-way, "packaged" marketing because it doesn't answer the questions they have when they are trying to buy, nor tell them what they need to know.

The views and phenomena described above is the background of the researcher's interest to make the problem of conversational style by male and female in business transaction at market. The result previous researchers above lead the researcher to conduct a research about conversational style but in different phenomenon, since differences between male and female language is very interesting. Therefore, the writer will do her study in the various way of making conversational style used by male and female seller especially at traditional market, because the writer wants to find out whether or not the differences of gender also exist in this area. So, in this study the researcher interest the conversational style used by male and female seller in business transaction at Pasar Sentosa Baru. In this case the researcher only will choose "sellers" in the market as research subjects because their selling positions are fixed and easily obtain data and interview them.

Based on the background, the researcher would like to know conversational style used by male and female sellers in business transaction, to elaborate the apprehensions of conversational style by male and female sellers in business transaction, and to investigates the reasons for the apprehensions in the ways they are.

\section{RESEARCH METHODOLOGY}

The research design of this study in business transaction male and female sellers were done in Pasar Sentosa Baru for around one months. The researcher recorded their conversation and moved it into transcribed text and then analyzed their utterances that relate to the types of conversational style based on Swann (2000).

The data got from business transaction of male and female utterances in Pasar Sentosa Baru especially in types of conversational styles such as: amount of talk, interruption, conversational support, tentativeness, and compliment (Swann, 2000).

The data source of this study were Sellers for Male and Female who had joined in business transaction in Pasar Sentosa Baru. Male and Female as a seller to do of business trnsaction. Which as 
a seller of male did of business transaction with buyer of male and female. And seller of female did of business transaction with buyer of male and female. The total number of seller were 8 sellers which limited their age is 35-60 years, their education starting from elementary school to senior high school, their ethnic were Javanese and Bataknese, and they were traders of vegetables, spices, seafood, and fruits.

The design of this research is descriptive research by using qualitative research design through conversational analysis, since this research is intended to analyze the addressing terms in Business Transaction in Pasar Sentosa Baru. Cresswell (2001) states qualitative research involves fieldwork. Descriptive research involves collecting data in interview from people own language or spoken words and observables behavior.

Bogdan and Biglen (1982) state that qualitative research is descriptive. The data collected are in the form of words. The written results contain quotations from data to illustrate and substantiate the presentation. The data include interview transcripts and official records.

In qualitative research, a researcher usually had fixed schedule of what to be done, but the researcher was more like loosely schedule traveler than the other (Bogdan, 1992). And Ary and Razarviech (1979) define that the descriptive study is used to get certain information about certain phenomenon that happens when a study is conducted. One the other words it is intended to describe the variable or condition that really occurred in a certain situation.

The data was collected through observation and interview. The researcher applied observation in this research in order to obtain the data during male and female sellers doing conversation. According to Bogdan and Biklen (1992) in qualitative research, to collect the data are: 1) Observation, and 2) Interview sheets.

In analyzing the data, the researcher will use of interactive model of Miles, Huberman, and Saldana (2014). They elaborate several steps of analyzing data; they are data collection, data condensation, data display, and data verification or conclusion

\section{FINDINGS AND DISCUSSIONS}

The research found some findings as follows:

1. Conversational styles by male sellers in business transaction used four kinds of conversational styles. The four kinds of conversational styles used were amount of talk, interruption, conversational support, tentativeness, and compliment. The more dominant were used by male sellers in business transaction was amount of talk (30\%), interruption (26.7\%), conversational support (21.7\%), compliment (16.6\%), and the last was tentativeness (5\%). Conversational styles by female sellers in business transaction used four kinds of conversational styles. The four kinds of conversational styles used were amount of talk, interruption, conversational support, tentativeness, and compliment. But in female sellers in business transaction was different from 
male sellers in business transaction because the more dominant here was interruption (29\%), conversational support (24\%), amount of talk (23\%), tentativeness (15\%), and the last was compliment $(9 \%)$.

2. Process of conversational styles related to goods and services are created and exchanged through the close coordination of many persons, sometimes within a single village, and sometimes across global distances. Coordination of this kind requires intense communication. Complex product specifications and production schedules must be mutually understood, and intricate deals between trading partners must be negotiated. Conversational styles vary enormously around the world, and these contribute to a staggering variety of business styles. The success of business transaction depends mainly on the effectiveness of interchange between the sellers and buyers (purchasers).

3. Reasons of conversational style are behaved by male and female sellers because they want to establish or maintain their status in that group, express interst in their partner's conversation topic and support for expecting to keep conversation going, and also they are intersted in it to establish to connection of intimacy to their partner of conversation.

\section{DISCUSSION}

From the finding obtained, there are some points which need to be discussed more deeply pertaining to conversation style found in business transaction at market:

1. All of kinds of conversational style are uttered by male and female sellers in businness transaction in traditional market at Pasar Sentosa Baru. Based on elaboration in findings that the kinds of conversational style such as: amount of talk, interruption, conversational support, tentativeness, and compliment. All of kinds are uttered by male and female sellers in business transaction at traditional market. In this study, we can see that female sellers dominantly used interruption than male do with total utterances are 19 and 16, and male sellers dominantly used compliment than female sellers do with total utterances are 10 and 6 These are differently from Swann (2000).

2. Different way of conversation between male and female sellers in business transaction. From explanation of data analysis previously proposed that male sellers used dominantly amount of talk for female sellers in their conversation in business transaction at Pasar Sentosa Baru Medan. Male sellers talk much in interaction in public context, they tendency it is public context it is conducted that they feel and also the effect of bargain in market, and also want to convince buyers that the merchandise they sell is cheap and of very good quality. Usually women talk very much, but in business transactions in this market the women do not talk too much different from their daily life, they only talk if needed.

3. The reason of male and female sellers used different style in business transaction at Pasar Sentosa Baru Medan. After finding out difference way of male and female sellers in their 
communication, in fact it still need to be peeled up the reason of its occurence. Reason why do male and female sellers used different style in their interaction, because male and female sellers have different characteristic in social life. These characteristic are conducted as the reason of male and female sellers used different style in business transaction in market.

\section{CONCLUSION}

After analyzing the data in kinds of conversational styles in male and female in business transaction in traditional market, some conclusions are drawn as the following:

There are five kinds of conversational styles in business transaction especially in traditional market, and all of kinds used by male and female sellers in business transaction in traditional market at Pasar Sentosa Baru Medan. They are amount of talk, interruption, conversational support, tentativeness, and compliment.

Further, male and female sellers used conversational style with their each way, based on the feature of conversational to do in business transaction at market to buyers. The features of conversational style are amount of talk, interruption, conversational support, tentativeness, and compliment. Based on the data kinds of conversational style used by male sellers are higher in using amount of talk than female sellers do in business transaction at market, and kinds of conversational style used by female sellers are higher using interruption than male sellers do in business transaction at market. In business transaction, female sellers have habit so only as needed speak in bargaining market, and for male sellers used amount of talk to show and make sure the quality of their goods are good and to make a good relationship with buyers.

Furthermore, Male and female sellers used conversational style differently in Business Transaction at Pasar Sentosa Baru Medan, it is because male and female sellers have different characteristics, and these characteristics have affected them to be having different style in doing interaction of Business Transaction at Pasar Sentosa Baru Medan.

\section{SUGGESTIONS}

Some suggestion that would like to suggest are for Bataknese sellers should use soft intonation while selling, so that buyers are not afraid to shop for goods in our place. Then, for all sellers should use good communication can help traders achieve good profits too and adds the buyer to always come to shop to their place especially in traditional market at Pasar Sentosa Baru Medan. And the last for all another ethnic sellers should compete in a healthy manner in business by selling good quality products and communicating and serving well.

\section{REFERENCES}


Ary, D., Jacobs, L.C. (2002). Introduction to Research in Education. USA: Wadsworth Group.

Bogdan, and Biklen. (1992). Qualitative Research for Education; An Introduction to Theory and Method. Boston: Allyn and Bacon. Clampitt, P.G. 2005. Communicating for Managerial Effectiveness. Sage. CA.

Coates, J. (1986). Women, Men and Language: A Sociolinguistic Account of Gender Differences in Language. London: Longman.

Coates, J. (1996). Women Talk: Conversation between Women Friends. Oxford: Blackwell.

Holmes, J. (1998). Women's Talk: The Question of Sociolinguistic Universals. In Wardhaugh, (2010).

Holmes, J. and Meyerhoff, M. (1999). The Community of Practice: Theories and Methodologies in Language and Gender Research. Language in Society, 28 (2). 173-183. doi: 10.1017/S004740459900202X

Lakoff, R. (1975). Language and woman's place. New York: Harper \& Row.

Lakoff, R.T. (J973). The logic of politeness; or. minding your p's and q's. In C. Corum, T.C SmilbSlark \& A. Weiser (Eds.), Papers from the Ninlh Regional Meeting of the Clurag., Lingulslics Society (pp. 292-305). Chicago, III.: Chicago Linguistics Society.

Lakoff, R.T. (1979). Stylistic strategies within a grammar of style. In J. Orasanu, M. Slater \& Ll Adler (\&is.), Language. sex, and gender (Annals of the New York Academy of Scleoco. 327. 5378). New York: The New York Academy of Sciences.

Miles., Huberman., \& Saldana. (2014). Qualitative Data Analysis. USA: Sage.

Swann. (2000). Girls, Boys and Language.Oxford: Blackwell.

Tannen (1987). "Conversational Style". Psycholinguistic Models of Production. Norwood, NJ: Ablex. pp. 251-267. 